\title{
SCIENCE IN BERLIN
}

$\mathrm{D}$ URING the seven days beginning May 24, a scientific conference was held in Berlin and was attended by delegates from many parts of the world. It was held under the patronage of the Burgomaster of Berlin, Prof. Ernst Reuter; the Senate of the City of Berlin; and the Plenipotentiary of the German Federal Republic, Dr. Heinrich Vockel. The Conference was organized with the support of the Gesellschaft Deutscher Chemiker, and its president, Prof. K. Ziegler, paid tribute to Prof. J. D'Ans who, as president of the Berlin branch of the Gesellschaft, had been largely responsible for the idea of holding the Conference and for its organization. The bodies which acted as hosts were: the Freie Universität Berlin, the Technische Universität Berlin, the Deutsche Forschungshochschule Berlin-Dahlem, the Ortsverband der Gesellschaft Deutscher Chemiker and the Berliner Physikalische Gesellschaft.

The Conference demonstrated very clearly that Berlin again has an important part to play in academic and scientific affairs, and it provided a valuable occasion for Berlin scientific workers to meet their colleagues from other parts of Germany and to discuss their scientific problems. It was the first major scientific conference to have been held in Berlin after the War, since most of the recent conferences have been held in the Federal Republic of Western Germany. It was attended by students of the Berlin Universities, including the Humboldt University in the Eastern Sector. Nearly 2,500 tickets were sold to participants, about 800 of these to residents of the Eastern Zone of Germany or the Eastern Sector of Berlin.

The scientific papers were formally divided into two main groups : the first on chemical problems in living processes; the second on problems of atomic physics, molecular physics and cosmogony. The large number of papers contributed at the Conference (some sixty or so in number) covered a wide range of chemistry, physics and physical techniques ; eight of the papers were from the Eastern Zone of Germany and four from the Eastern Sector of Berlin.

The visiting foreign men of science, many of whom read papers, were: Prof. H. J. Hildebrand, University of California; Dr. J. R: Johnson, Cornell University; Dr. Miller, Minnesota Mining and Metallurgical Corporation; Prof. P. Niggli, Technische Hochschule, Zurich; Prof. J. A. Hedvall, Göteborg; Prof. R. Domenjoz, Saarbrücken; H. Nitschmann, Bern; Prof. H. S. W. Massey, London; Dr. F. P. Bowden, Cambridge; Prof. Chrétien, Paris. The Conference was held in the premises of the Technical University (Berlin-Charlottenburg), and at the ceremonial gathering the rector, Prof. W. Pflaum, laid stress on the important part that the fundamental and exact sciences play in technology. Dr. Vockel said that he envied the natural scientists their comparatively simple task of discovering the natural laws which govern the physical world. He appealed for their understanding of, and sympathy for, the politician who is attempting the difficult and urgent task of discovering the laws which govern the social order. Dr. Tiburtius, as Senator for Education in the City of Berlin, spoke of the attitude of the State towards science, which should not be to harness it for political ends, but to co-operate with scientific workers and to assist them in the free pursuit of their researches. The other speakers were Prof. M. von Laue, president of the Kaiser-Wilhelm-Institut, Berlin-Dahlem; Prof. Ziegler; Prof. Hans von Kress, rector of the Free University. Prof. C. Ramsauer, president of the Berlin Physical Society, gave an account of the part which Berlin scientific men have played, particularly in modern physics and chemistry. Measured by any yardstick this is impressive, and it was interesting to note that of the total of thirty-four Nobel Prizes which have been awarded to German physicists and chemists, eleven were gained by Berlin scientific workers. Prof. P. Niggli (Switzerland) spoke on behalf of the foreign men of science and paid tribute to Berlin's record in the natural sciences.

The first session began with a paper on photosynthesis by Prof. O. Warburg, and the physics session on radioactivity, which was under the chairmanship of Prof. J. D'Ans and Prof. M. von Laue, was opened with a paper from Prof. O. Hahn. This opening session was attended by Major-Ceneral G. K. Bourne, General Officer Commanding Berlin (British Sector), by Dr. Vockel, and by representatives of the British, American and French Scientific Research Divisions.

Those attending the Conference worked hard during the day, and in the evenings were entertained at various social functions, both official and private. These included a reception given by Dr. Vockel ; an evening at the ballet "Abraxas", followed by a reception given by the Senator for Education, the Rector of the Technical University and the Rector of the Free University. At this reception a presentation was made to Herr Werner Egk, composer of the ballet. A reception was also given by the Mayor and Senate of Berlin. In addition to this, there were student gatherings and entertainments. Visits were paid to various research laboratories, many of which are admirably equipped and which are carrying out work of a high standard.

The Conference was held in an atmosphere of lively interest and enthusiasm, and it was impressive to see how science can transcend all political difficulties. The attendance was very large; in the physics session, for example, it was well over a thousand, a big proportion being students. The whole Conference was admirably organized, and it reflects great credit on Prof. D'Ans and the organizing committees. It is clear that science in Berlin is very much alive, and tribute must be paid to the devotion and courage of those who have built it up under such difficult conditions.

F. P. BOWDEN

\section{A CENTURY OF DEVELOPMENTS IN ENGINEERING}

A "JOINT Engineering Conference, 1951", organA ized by the Institutions of Civil, Mechanical, and Electrical Engineers, was held in London during June 4-15. A large number of papers reviewing the development of different branches of engineering during the past hundred years were read.

One group of papers dealt with mechanical engineering developments in the mercantile marine, on the railways, in the gas industry, in electricity power stations, in road transport vehicles and in the iron and steel industry. Mr. R. A. Crowe outlined the 